\title{
EVALUATION OF HEAVY METALS LEVEL OF SOIL IN OLD PANTEKA MARKET AREA OF KADUNA, NIGERIA
}

\author{
${ }^{1}$ Funtua, M .A. Jimoh A., ${ }^{2}$ Agbaji, E .B. ${ }^{2}$ and Ajibola, V .0. ${ }^{2}$ \\ ${ }^{1}$ Department of pure \& applied chemistry, Federal University Birnin kebbi, Kebbi State, Nigeria \\ ${ }^{2}$ Department of Chemistry, Ahmadu Bello University, Zaria, Kaduna State, Nigeria \\ Correspondence:M.A. Funtua, Department of pure \& applied chemistry, Federal University Birnin kebbi, Kebbi \\ State,. Tel: +234-8039738584. E-mail: adomustapha@yahoo.com.
}

\begin{abstract}
The aim of this research is to determine the level and distribution of $\mathrm{Cu}, \mathrm{Cd}, \mathrm{Cr}, \mathrm{Pb}$ and $\mathrm{Ni}$ from soils samples within the vicinities of Old Panteka market of Kaduna state, Nigeria. The design of this study is to compare the soil heavy metal concentrations with regulatory standard values permitted by the Nigerian environmental guideline as well as international standards and also subject the data to descriptive analysis to determine the correlation between the heavy metals and some physicochemical parameter. Forty-four soil samples at 0 to $5 \mathrm{~cm}$ and 5 to $10 \mathrm{~cm}$ depths from ten (10) sample locations and one control sample was collected on the same day at Old Panteka market of Kaduna, Nigeria. The total concentrations of $\mathrm{Cu}, \mathrm{Cr}, \mathrm{Cd}, \mathrm{Pb}$ and Ni were determined using Atomic Absorption spectrophotometer. Cation exchange capacity (CEC), pH, electrical conductivity (EC) and particle size distribution of the soil samples were also determined. The mean concentrations of heavy metal of the metal/welding soils at $0-5 \mathrm{~cm}$ were; $\mathrm{Cr}: 0.00$ $113.95 \mathrm{mg} / \mathrm{kg}$, Cu: 15.68 - $2550.53 \mathrm{mg} / \mathrm{kg}$, Cd: $1.33-6.30 \mathrm{mg} / \mathrm{kg}$, Pb: $116.30-1220.45 \mathrm{mg} / \mathrm{kg}$, Ni: 9.35 - $145.05 \mathrm{mg} / \mathrm{kg}$, while at $5-10 \mathrm{~cm}$, the ranges were; Cr: $0.10-161.73 \mathrm{mg} / \mathrm{kg}$, Cu: 16.00 $3446.43 \mathrm{mg} / \mathrm{kg}$, Cd: 1.28 - $11.23 \mathrm{mg} / \mathrm{kg}$, Pb: $95.85-958.40 \mathrm{mg} / \mathrm{kg}$, Ni: $14.18-170.78 \mathrm{mg} / \mathrm{kg}$. The concentrations of the studied metals in the soils from the experimental sites were higher than the corresponding values from the control site at both depths with a general increase in metal concentration with soil depth in most of the sites. Results of the heavy metals in the soils of the experimental sites indicated that the metals were mostly above the European commission (1986) recommended limits for these metals in soil with few exceptions.
\end{abstract}

Keywords; Soil; heavy metals; Correlation; Atomic Absorption spectrophotometer; Cation exchange capacity (CEC); pH; electrical conductivity (EC); Particle size

\section{INTRODUCTION}

Heavy metals are common environmental pollutants and are released into soils from natural or anthropogenic sources. The main natural sources of metals in soils are weathering of parent materials and soil erosion(Yoon et.al 2007). The anthropogenic sources are associated mainly with industrial activities such as metal finishing, paint pigment and battery manufacturing, leather tanning, mining activities, foundries and smelters, diffuse sources e.g., piping, constituents of products, combustion byproducts, traffic emissions and other human activities like urban composts and municipal waste water sludge depositions and use of pesticides and phosphate fertilizers (Omar and Alkhashman, 2004; Boularbah et al., 2006). Soils are the major sinks for heavy metals released into the environment by aforementioned anthropogenic activities and unlike organic contaminants which are oxidized to carbon (IV) oxide by microbial action, most metals do not undergo microbial or chemical degradation but undergo oxidation to cations in the presence of moisture and oxygen (Kirpichtchkova et al., 2006) and the total concentration of heavy metals in soil persist for a long time after their introduction (Andriano, 1986). In Nigeria and many developing countries, many industrial workshops such as welding workshop, mechanical and electrical workshops are located by the roadsides in residential areas where their customers could easily have access to them. The wastes produced in these workshops are potential environmental pollutants that need to be given a serious attention. Welding is a process in which two or more pieces of metal are joined together by the application of heat, pressure or a combination of both (Disc, 1981).

With the development of new techniques arising in the first half of the 20th century, welding replaced bolting and riveting in the construction of many types of structures, including bridges and building. It is also a basic process in the motor and aircraft industries and in the manufacture of food machinery. Along with soldering and brazing, it is essential in the production of virtually every manufactured product involving metals (Disc, 1981; Odukoya et al., 2000). The welding processes most commonly employed today are gas and electric welding. The impact of these processes on the environment must be given attention. Contamination of the environment by metals can cause interference with plant metabolism and consequently the food chain. 
BAJOPAS Volume 10 Number 1 June, 2017

This is because the conversion of nitrate is inhibited so that the supply of the nitrogen available to the plant is reduced (Cook, 1976). It is worthy of note that the major industrial activities in old Panteka market area are welding of metals alongside soldering. However due to a tremendous increase in population and vehicular traffic, as well as the creation of a variety of ancillary activities such as vehicle repairs, vulcanizer, auto electricians, and battery chargers etc. These activities result in heavy metals contamination of soils. Although few studies conducted on these workshops have been reported for some small and medium-size cities in the country namely: Iwo (Ipeaiyeda et al., 2008), Port Harcourt (Iwegbue, 2009), Akure (Ilemobayo et al., 2008), and locations in the Imo river basin (Nwachukwu et al., 2010), there is a need to conduct studies in bigger cities so that more definitive conclusions can be made for the country as a whole.

Using Kaduna (old Panteka) as a case study, this research would be carried out to look at these welders workshops closely and make conclusions regarding the heavy metals contamination of the soil environment where they are located. There is, therefore, need for a continuous monitoring of the level of heavy metal in the area in order to keep a check on the environment and to provide data for future research works.

\section{MATERIALS AND METHODS}

In the present study, soil samples were collected from ten (10) selected locations in old Panteka, Kaduna. Global Positioning System device model eTrex HC series was used to measure the coordinates of each sampling point around the old Panteka market where most artisanal welding activities occur namely; Mallam madori close (MMC), Pick-up garage (PUG), Gulubi Junction (GUJ), Poly Junction (POJ), Mallam madori Road before bridge (MMR), Hamzy Metal Construction (HMC), Masallaci Street (MAS), Opposite Police Station (OPS), Police Station road Junction (PSR), Adjacent Baptist Church (ABC) and Malumfashi Close located at Malumfashi road as a control site about $1 \mathrm{Km}$ away from old Panteka market, which is largely a residential area and the soil samples were collected at depths of $0-5 \mathrm{~cm}$ and $5-10 \mathrm{~cm}$. The soil surface was cleared with a plastic hand trowel to a depth of approximately $20 \mathrm{~cm}$ before the samples were collected using a plastic spoon at $0-5 \mathrm{~cm}$ and $5-10 \mathrm{~cm}$ depth. After every collection, the plastic hand trowel and spoon were washed with soap and rinsed with distilled water to avoid sample contamination(Awofolu,2005). Five soil samples from each sampling location and depths were randomly collected and pooled together to form a composite from each of the sampling locations. The control samples were collected to validate the heavy metal concentration in soil and labeled control sample from Malumfashi close that is majorly residential with low traffic volume and industrial activities. A total of forty-four (44) soil samples were collected on the same day. The collected soil samples were stored in a polyethylene bag, labeled properly and taken to the laboratory where the $\mathrm{pH}$ was measured immediately and recorded using digital analyzer model Grison MicropH 2000.

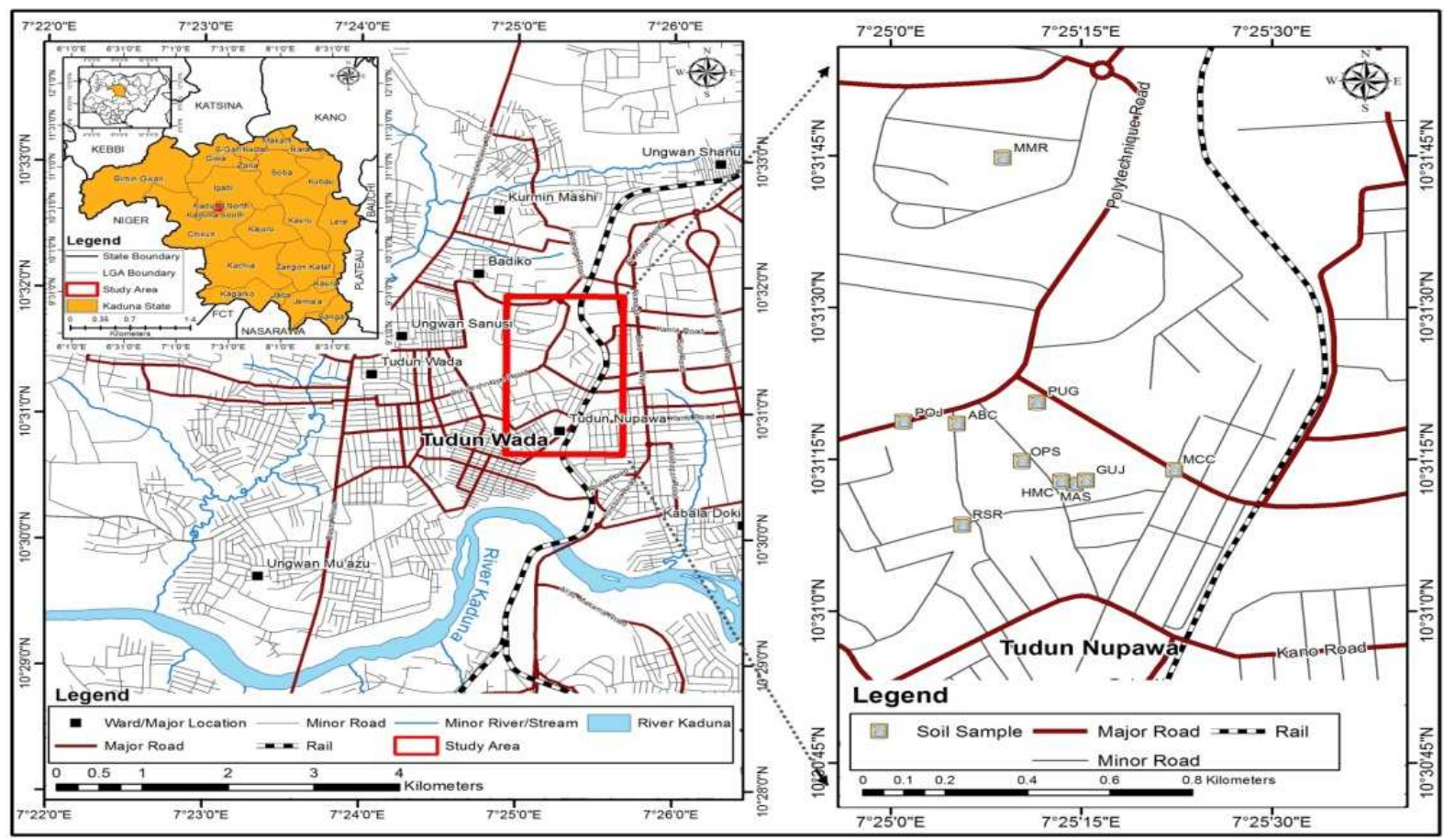

Figure 1: Map of Kaduna Metropolis showing Soil Sampling Points Source: Fieldwork

\section{Sample pre-treatment}

The collected study samples and the control were airdried at room temperature, disaggregated in a ceramic pestle and mortar, and sieved through a 2 $\mathrm{mm}$ sieve to remove stones and pebbles. 
The $<2 \mathrm{~mm}$ fractions of the soil were stored in cellophane bags and used for all soil analyses. Particle size distribution $\mathrm{w}$ determined by Bouyoucos hydrometer method (Bouyoucos, 1951) and $\mathrm{pH}$ was determined by Electric pH Meter (Grison MicropH 2000) with a direct readout. Electrical conductivity was measured by a high powered microcomputer conductivity meter HANNA HI 9828. Cation exchange capacity was determined by the Black, 1965 procedure. The total heavy metal content was determined using atomic absorption spectrophotometer (Varian model AA650FS) at Multiuser Science Research Laboratory, Ahmadu Bello University, and MSc. Laboratory respectively, while the physicochemical parameters were carried out in the department of soil science Laboratory at Institute of Agricultural research Samaru, Zaria Nigeria.

\section{Quality Control}

As part of quality control measure to ensure the reliability of results, samples were handled carefully to avoid contamination. Recovery test was carried out on the AAS machine by spiking analyses, Validation of the technique was conducted on the soil samples. This was done by spiking the pre-digested samples with a multi-element standard solution $(5 \mathrm{mg} / \mathrm{L}$ of $\mathrm{Cd}$, $\mathrm{Cu}, \mathrm{Ni}, \mathrm{Pb}$, and $\mathrm{Cr}$ ) as reported by Awofolu (2005).

\section{RESULTS AND DISCUSSION}

\section{Physicochemical Properties}

The result of the analyses of the physicochemical parameters of the welding workshops and the control site soil are presented in Tables 1 and 2 . The particle size distribution of the workshop soil samples ranged from $7.41 \%-25.97 \%$ for clay, $11.12 \%-18.48 \%$ for silt and $59.21 \%-77.77 \%$ for sand at $0-5 \mathrm{~cm}$ depth, while at $5-10 \mathrm{~cm}$ depth, the workshop soils ranged from $8.40 \%-30.97 \%$ (clay), $12.12 \%-18.89 \%$ (silt) and $54.21 \%-75.12 \%$ (sand). The values recorded at the control sites were $18.40 \%$ (clay), $15.90 \%$ (silt) and $65.70 \%$ (sand) at $0-5 \mathrm{~cm}$ and $5-10 \mathrm{~cm}$ depths respectively. The soil textural class is basically sandyloamy. The $\mathrm{pH}$ values obtained from soils in the study area ranged from $7.42-10.32$ at $0-5 \mathrm{~cm}$ and $7.49-$ 10.45 at $5-10 \mathrm{~cm}$ depths which was alkaline in nature at both depths while at the control site, it was $8.53(0-5 \mathrm{~cm})$ and $8.47(5-10 \mathrm{~cm})$ indicating also alkaline nature. $\mathrm{pH}$ plays a significant role in solute concentration and in sorption and desorption of contaminants in soil (Gillman, 1981; Elliot et al., 1986). It is an important and useful index of the availability of nutrients, the potency of toxic substances present in the soil and the physical properties of the soil (Iwegbue et al., 2009). The alkaline $\mathrm{pH}$ values of the soils might be as a result of the sorption of metals in the soil (Lee and Saunders, 2003). The $\mathrm{pH}$ values obtained in this study are similar to that reported for dumpsites by other researchers (Uba et al., 2008; Elaigwu et al., 2007; Gupta and Sinha, 2006). The ranges of values obtained in this study are within the range of 6.80 8.20 and 6.50 - 8.30 reported by Aruleba and Ajayi (2012) and Inobeme et al., 2014 respectively. It is, however, higher than 3.60 - 6.73 as reported by Osakwe (2014). The presence and mobility of heavy metals in the soil are affected by the $\mathrm{pH}$ of the soil. The implication of soil $\mathrm{pH}$ variations with depths can be attributed to the oxidation states of certain heavy metals. The conductivity of a heavy metal which is proportional to the mobility and metal concentration is highly dependent on the redox state.

The $\mathrm{As}^{3+}$ forms are significantly more mobile and toxic in the environment than the $\mathrm{As}^{5+}$ species (Rajaković et al., 2013). The EC values were found to vary significantly across the sites; Tables: 1 and 2. EC serves as a measure of soluble nutrients (Smith and Doran, 1996) for both cations and anions and is useful in monitoring the mineralization of organic matter in the soil (De Neve et al., 2000). The results of EC were quite high with values ranging from 0.32 $11.20 \mu \mathrm{s} / \mathrm{cm}$ across depths. These may be due to the indiscriminate disposal of metal scraps by artisans at the old Panteka industrial area onto the soil and eventually into the well water. These values were higher than the values reported by Osakwe and Ofuya (2008) and Oviasogie and Omoruyi (2007). The high E.C of soils is an indication of the high or significant presence of ions. The observed E.C values in the workshops soil could be attributed to the reactions between some depositions containing metals from vehicular scraps and some metals, resulting in the availability of some soluble and ionizable inorganic salts in the soils. The EC values were higher than those obtained in scrap dump sites in Warri by Iwegbue et al., (2009) (0.13 - $\left.0.28 \mu \mathrm{scm}^{-1}\right)$. These results were lower when compared to $140 \pm 28.30$ to $530 \pm 28.20$ as reported by Inobeme et al., (2014), in soils around paint industries in Kaduna. The discrepancy in the electrical conductivity values could be as a result of the differences in the soluble salts content of the soil. CEC of heavy metals depends on the density of ionic strength of the surfaces of soil colloids and on the relative charges of metal species in the soil solution. The surface negative charges may be $\mathrm{pH}$ dependent (soil organic matter) (Evans, 1987). Cations are less bioavailable because they have less competition from $\mathrm{H}^{+}$for available binding sites. According to Awode et al., (2008), CEC of soil is more greatly influenced by organic matter than by the concentration of clays, hence CEC tends to be higher in most study sites than in the control sites. On variation with soil depth, the CEC values of some of the study areas decreased down the soil profile. This reduction in CEC of the studied soil down the profile is a reflection of nutrient-depleting wastes or displacement by toxic metals which are indirectly introduced through the indiscriminate disposal of waste and metal scraps.

\section{Total Heavy Metal Concentration}

\section{(Mean $\mathrm{Cr}$ concentrations)}

The mean level of $\mathrm{Cr}$ in the workshop soils ranged from $0.00 \mathrm{mg} / \mathrm{kg}-113.95 \mathrm{mg} / \mathrm{kg}$ at $0-5 \mathrm{~cm}$ depths. However higher values of $0.10-161.73 \mathrm{mg} / \mathrm{kg}$ were recorded at $5-10 \mathrm{~cm}$ depth, this could be due to leaching effect of chromium containing metals or solders from welding activities taken place at the workshops. Chromium concentrations in the workshop soils were generally above standard limits (0.03 $\mathrm{mg} / \mathrm{kg}$ ) set by FEPA (1991). Sources of $\mathrm{Cr}$ in the soils could be due to automobiles scraps, coloured polyethylene bags, discarded plastic materials and empty paint containers (Jung et al., 2006). 
(Mean Cu concentrations)

Copper had relatively high values ranging from 15.68

- $2550.53 \mathrm{mg} / \mathrm{kg}$ at $0-5 \mathrm{~cm}$ and $16.00-3446.43$ $\mathrm{mg} / \mathrm{kg}$ at $5-10 \mathrm{~cm}$ depths. The exceptionally high

values in Gulubi Junction (GUJ) and

Table 1: Physicochemical parameters of welding workshop soils and control site at $0-5 \mathbf{c m}$ depth

\begin{tabular}{cccccccc}
\hline SITE CODES & $\begin{array}{c}\text { Clay } \\
(\boldsymbol{\%})\end{array}$ & $\begin{array}{c}\text { Silt } \\
(\boldsymbol{\%})\end{array}$ & $\begin{array}{c}\text { Sand } \\
\mathbf{( \% )}\end{array}$ & $\begin{array}{c}\text { Texture } \\
\text { Class }\end{array}$ & $\mathbf{p H}$ & EC $(\boldsymbol{\mu s} / \mathbf{c m})$ & CEC $(\mathbf{C m o l} / \mathbf{k g})$ \\
\hline GUJ & 7.41 & 16.89 & 75.97 & S-L & $7.48 \pm 0.08$ & $2.85 \pm 0.01$ & $33.50 \pm 0.01$ \\
MMC & 7.41 & 14.82 & 77.77 & S-L & $8.15 \pm 0.00$ & $2.42 \pm 0.03$ & $37.81 \pm 0.01$ \\
OPS & 25.97 & 18.47 & 59.21 & S-L & $7.42 \pm 0.03$ & $0.32 \pm 0.03$ & $33.63 \pm 0.03$ \\
MMR & 18.47 & 11.12 & 70.41 & S-L & $8.33 \pm 0.03$ & $2.40 \pm 0.00$ & $32.86 \pm 0.01$ \\
ABC & 18.47 & 18.48 & 74.11 & S-L & $10.32 \pm 0.03$ & $5.62 \pm 0.03$ & $50.32 \pm 0.03$ \\
PSR & 9.41 & 14.82 & 75.77 & S-L & $9.42 \pm 0.03$ & $9.70 \pm 0.00$ & $62.35 \pm 0.01$ \\
HMC & 9.92 & 14.82 & 75.26 & S-L & $9.50 \pm 0.00$ & $5.10 \pm 0.00$ & $46.10 \pm 0.00$ \\
PUG & 10.41 & 12.97 & 76.62 & S-L & $9.80 \pm 0.00$ & $1.40 \pm 0.00$ & $50.37 \pm 0.00$ \\
POJ & 9.26 & 15.97 & 74.77 & S-L & $8.72 \pm 0.03$ & $11.05 \pm 0.00$ & $51.95 \pm 0.01$ \\
MAS & 7.56 & 16.18 & 76.26 & S-L & $9.05 \pm 0.00$ & $0.70 \pm 0.00$ & $41.21 \pm 0.00$ \\
CONTROL & 18.40 & 15.90 & 65.70 & S-L & $8.53 \pm 0.06$ & $4.10 \pm 0.00$ & $39.41 \pm 0.00$ \\
\hline
\end{tabular}

S-L: Sandy-Loamy.

Key: GUJ: Gulubi Junction; MMC: Mallam madori close; OPS: Opposite Police Station; MMR: Mallam madori Road before bridge; ABC: Adjacent Baptist Church; PSR: Police Station road; HMC :Hamzy Metal Construction; PUG: Pick-up garage; POJ: Poly Junction; MAS: Masallaci Street

Hamzy Metal Construction (HMC) welding workshop could be attributed to welders and smelters activities containing copper wires, electrodes, copper pipes and alloys from corroding metals and soldering process which have littered the vicinity for a long period of time, with the metals released from the corrosion gradually leaching into the soil (Nwanchukwu et al.,
2011). The levels of $\mathrm{Cu}$ recorded in this study were higher than those recorded in soils of auto mechanic sites in Makurdi by Aloysius et al., (2013). Copper concentrations in most studied sites were above standard limits $(140 \mathrm{mg} / \mathrm{kg})$ set by European commission (1986). The mean copper values in the control sites were lower than those in the study areas.

Table 2: Physicochemical parameters of welding workshop soils and control site at $5-1 \mathrm{~cm}$ depth

\begin{tabular}{cccccccc}
\hline $\begin{array}{c}\text { SITE } \\
\text { CODES }\end{array}$ & $\begin{array}{c}\text { Clay } \\
\mathbf{( \% )}\end{array}$ & $\begin{array}{c}\text { Silt } \\
(\boldsymbol{\%})\end{array}$ & $\begin{array}{c}\text { Sand } \\
\mathbf{( \% )}\end{array}$ & $\begin{array}{c}\text { Texture } \\
\text { Class }\end{array}$ & $\mathbf{P h}$ & EC $(\boldsymbol{\mu s} / \mathbf{c m})$ & $\begin{array}{c}\text { CEC } \\
(\mathbf{C m o l} / \mathbf{k g})\end{array}$ \\
\hline GUJ & 10.92 & 18.89 & 70.46 & S-L & $7.52 \pm 0.06$ & $2.72 \pm 0.23$ & $33.48 \pm 0.10$ \\
MMC & 8.41 & 15.82 & 72.46 & S-L & $8.33 \pm 0.08$ & $2.52 \pm 0.08$ & $37.82 \pm 0.03$ \\
OPS & 30.97 & 14.82 & 54.21 & S-L & $7.49 \pm 0.06$ & $0.42 \pm 0.08$ & $33.65 \pm 0.05$ \\
MMR & 18.68 & 12.12 & 69.20 & S-L & $8.43 \pm 0.06$ & $2.45 \pm 0.05$ & $32.85 \pm 0.05$ \\
ABC & 8.40 & 16.48 & 75.12 & S-L & $10.45 \pm 0.01$ & $5.74 \pm 0.03$ & $50.30 \pm 0.05$ \\
PSR & 9.43 & 17.82 & 72.75 & S-L & $9.42 \pm 0.03$ & $9.80 \pm 0.05$ & $62.38 \pm 0.08$ \\
HMC & 9.92 & 15.62 & 74.46 & S-L & $9.72 \pm 0.03$ & $5.25 \pm 0.05$ & $45.15 \pm 0.05$ \\
PUG & 12.40 & 12.98 & 72.62 & S-L & $9.77 \pm 0.14$ & $1.47 \pm 0.03$ & $50.42 \pm 0.02$ \\
POJ & 9.30 & 16.10 & 74.60 & S-L & $8.67 \pm 0.03$ & $11.20 \pm 0.13$ & $51.97 \pm 0.03$ \\
MAS & 11.54 & 18.20 & 70.26 & S-L & $9.32 \pm 0.38$ & $0.75 \pm 0.05$ & $41.57 \pm 0.59$ \\
CONTROL & 18.40 & 15.90 & 65.70 & S-L & $8.47 \pm 0.08$ & $4.25 \pm 0.05$ & $39.44 \pm 0.03$ \\
\hline
\end{tabular}

S-L: Sandy-Loamy

Key: GUJ: Gulubi Junction; MMC: Mallam madori close; OPS: Opposite Police Station; MMR: Mallam madori Road before bridge; ABC: Adjacent Baptist Church; PSR: Police Station road; HMC :Hamzy Metal Construction; PUG: Pick-up garage; POJ: Poly Junction; MAS: Masallaci Street

\section{(Mean Cd concentrations)}

Workshop soil heavy metal contents were significantly lower in the control site compared to the study areas. Cd concentrations in the workshop soils were above the standard limits $(3 \mathrm{mg} / \mathrm{kg}$ ) set by European commission (1986) with the exception of sites Mallam madori close (MMC), Opposite Police Station (OPS), Mallam madori Road before bridge (MMR), Adjacent Baptist Church $(A B C)$, Police Station road Junction (PSR), Poly Junction (POJ) welding sites and the Control site (Table: 3 ). The high concentrations of $\mathrm{Cd}$ at some study areas could be attributed to metallic alloys used during the process of smelting, soldering, and welding. Cd exhibited lower levels of contamination than those of the other metals studied. The mean value obtained in soils of auto mechanic sites in Makurdi by Aloysius et al., (2013) (12.79 $17.90 \mathrm{mg} / \mathrm{kg}$ ) and in Owerri Municipal by Okoro et al., (2013) $(8.83-18.67 \mathrm{mg} / \mathrm{kg})$ in a similar studies were higher than those reported in this study. The results were also below those reported in soil of abandoned mechanic workshops in Umuahia metropolis by Abii (2012) (19.4 - $25.6 \mathrm{mg} / \mathrm{kg})$, but above those reported in Abbatoir dumpsite in Yauri, Kebbi state by Yahaya et al., (2009) (0.14 - $7.00 \mathrm{mg} / \mathrm{kg})$, and in municipal waste dumpsites in Benin city by Osaze et al., (2013) (0.009 - $0.016 \mathrm{mg} / \mathrm{kg})$. 


\section{(Mean $\mathbf{P b}$ concentrations)}

Lead concentration in most of the study areas was generally below the standard limits $(300 \mathrm{mg} / \mathrm{kg}$ ) set by European commission (1986). The exceptionally high value in sites Masallaci Street (MAS) (1220.45 $\mathrm{mg} / \mathrm{kg}$ ) at $0-5 \mathrm{~cm}$ and Gulubi Junction (GUJ) welding sites $(958.40 \mathrm{mg} / \mathrm{kg})$ at $5-10 \mathrm{~cm}$ depths, could be attributed to the metals fabrication and smelting activities taken place in the welding workshops. It is possible that these high levels of $\mathrm{Pb}$ are elevated by the amount of waste such as scraps from metals, liquid emission from welding machine, used welding electrodes indiscriminately dumped by smelters and welders in the study area. The levels of $\mathrm{Pb}$ recorded in this study are above those recorded in soils of auto mechanic sites in Akure by Oguntimehin and Ipinmoroti, (2008). Values of $(1.23-3.43 \mathrm{mg} / \mathrm{kg})$ reported by Adewole et al., (2010) in automobile workshops in Ile-Ife; $25.85-38.83 \mathrm{mg} / \mathrm{kg}$ by Abii (2012) in Umuahia metropolis and 33.64 - 117.45 $\mathrm{mg} / \mathrm{kg}$ by Atiemo et al., (2012) in Accra are lower than those reported in this study. However, concentration ranges of $283-665 \mathrm{mg} / \mathrm{kg}$ reported by Aloysius et al., (2013) in automobile workshops in Makurdi; 693 - $2917 \mathrm{mg} / \mathrm{kg}$ by Okoro et al., (2013) in Owerri municipal and $1162 \mathrm{mg} / \mathrm{kg}$ by Nwachukwu et al., (2011) in auto mechanic village, Owerri were higher than the concentration range reported in this study.

\section{(Mean Ni concentrations)}

The mean $\mathrm{Ni}$ concentration recorded at control site was the lowest at both depths (Tables: 3 ). The nickel concentration in the workshops soil was mostly above standard limits $(75 \mathrm{mg} / \mathrm{kg})$ set by the European commission for soil (1986) thus implying high contamination of the metal in the soil. This could be attributed to the indiscriminate disposal of spent electrodes by welders and various paint wastes use by welders, which have contributed to the contamination of the soil samples (Udousoro et al., 2010). The concentration range reported in this study was higher than concentration range values for soils of auto mechanic and refuse dumpsites in Makurdi by Luter et al., (2011) (4.20 - $48.6 \mathrm{mg} / \mathrm{kg})$, Scrap dumpsites in Warri by Iwegbue et al., (2009) (16.52 - 17.38 $\mathrm{mg} / \mathrm{kg}$ ) and auto repair workshops in Iwo by Ipeaiyeda et al., (2008) (11.5 mg/kg) in a similar study. The mean nickel values in the control site were observed to be lower than those in the studied areas. In general, the concentrations of metals found in the soils of the study areas are higher than the control site while the concentration of some metals decreased with soil depth.

Analysis of variance (ANOVA) between the heavy metals in the soils of the study areas and the control sites reveal significant differences $(P<0.05)$.

Table 3: Basic statistical parameters for the distribution of heavy metals in the investigated soil samples

\begin{tabular}{lllllllllll}
\hline \multicolumn{3}{l}{ Soil $\mathbf{( 0} \mathbf{- 5} \mathbf{~ c m})$} & & & & \multicolumn{2}{l}{ Soil $\mathbf{( 5 - 1 0 ~} \mathbf{~ c m})$} & & \\
Sites & $\mathbf{C r}$ & $\mathbf{C u}$ & $\mathbf{C d}$ & $\mathbf{P b}$ & $\mathbf{N i}$ & $\mathbf{C r}$ & $\mathbf{C u}$ & $\mathbf{C d}$ & $\mathbf{P b}$ & $\mathbf{N i}$ \\
\hline GUJ & 101.55 & 2550.53 & 5.35 & 1133.73 & 145.05 & 90.68 & 2692.73 & 7.30 & 958.40 & 170.78 \\
MMC & 15.45 & 111.20 & 1.68 & 203.45 & 25.10 & 8.58 & 183.60 & 1.28 & 140.80 & 40.00 \\
OPS & 21.03 & 151.50 & 1.43 & 243.28 & 36.23 & 8.80 & 190.53 & 1.35 & 219.75 & 50.35 \\
MMR & 28.65 & 464.35 & 1.35 & 116.30 & 46.23 & 27.63 & 1546.78 & 1.28 & 126.88 & 57.90 \\
ABC & 34.90 & 320.80 & 1.33 & 176.23 & 47.08 & 27.73 & 160.15 & 2.75 & 116.43 & 43.50 \\
PSR & 75.10 & 794.68 & 3.25 & 1158.88 & 102.70 & 161.73 & 514.15 & 2.20 & 337.00 & 120.43 \\
HMC & 82.33 & 2379.20 & 3.70 & 957.30 & 111.63 & 71.10 & 3446.43 & 4.50 & 853.68 & 156.53 \\
PUG & 113.95 & 349.33 & 6.30 & 902.08 & 100.50 & 82.80 & 350.48 & 11.23 & 674.48 & 108.93 \\
POJ & 11.48 & 906.85 & 1.65 & 187.95 & 45.83 & 26.00 & 167.43 & 2.10 & 216.68 & 55.33 \\
CONTROL & $\mathbf{0 . 0 0}$ & $\mathbf{1 5 . 6 8}$ & $\mathbf{1 . 4 5}$ & $\mathbf{2 1 9 . 3 0}$ & $\mathbf{9 . 3 5}$ & $\mathbf{0 . 1 0}$ & $\mathbf{1 6 . 0 0}$ & $\mathbf{1 . 5 5}$ & $\mathbf{9 5 . 8 5}$ & $\mathbf{1 4 . 1 8}$ \\
MAS & 43.93 & 434.60 & 5.78 & 1220.45 & 77.33 & 34.98 & 897.23 & 5.55 & 589.75 & 74.95 \\
Sum & 528.37 & 8478.72 & 33.27 & 6518.95 & 747.03 & 540.13 & 10165.51 & 41.09 & 4329.70 & 892.88 \\
Mean & 48.03 & 770.79 & 3.02 & 592.63 & 67.91 & 49.10 & 924.14 & 3.74 & 393.61 & 81.17 \\
S Dev & 137.87 & 2283.84 & 8.58 & 1698.84 & 192.27 & 143.15 & 2773.03 & 10.76 & 1129.69 & 229.86 \\
Min & 0.00 & 15.68 & 1.33 & 116.30 & 9.35 & 0.10 & 16.00 & 1.28 & 95.85 & 14.18 \\
Max & 113.95 & 2550.53 & 6.30 & 1220.45 & 145.05 & 161.73 & 3446.43 & 11.23 & 958.40 & 170.78 \\
\hline Source: Experimentation & & & & & & & &
\end{tabular}

Source: Experimentation

Key: GUJ: Gulubi Junction; MMC: Mallam madori close; OPS: Opposite Police Station; MMR: Mallam madori Road before bridge; ABC: Adjacent Baptist Church; PSR: Police Station road; HMC :Hamzy Metal Construction; PUG: Pick-up garage; POJ: Poly Junction; MAS: Masallaci Street

(Correlation Analysis of Soil Heavy Metals)

Heavy metals, $\mathrm{pH}$, EC and CEC Correlation coefficient measures the strength of a linear relationship between any two variables on a scale of -1 (perfect inverse relation) through 0 (no relation) to +1 (perfect sympathetic relation). In this study, the raw data was used in calculating the correlation coefficient using the Microsoft Excel computer software package (Microsoft corp., 2013 version). The correlation analysis between heavy metals in sample soils, $\mathrm{pH}, \mathrm{EC}$ and CEC are shown in (Tables: 4 and 5). Some of the heavy metals are significantly correlated with each other so also the $\mathrm{pH}$, EC and CEC are significantly correlated with each other at both depths. 
$\mathrm{Cr} / \mathrm{Ni}, \mathrm{Cu} / \mathrm{Ni}, \mathrm{Cd} / \mathrm{Pb}$ and $\mathrm{Pb} / \mathrm{Ni}$ are correlated positively with each other at $0-5 \mathrm{~cm}$ depth with values +0.927 , +0.800 , +0.874 and +0.860 , and also +0.770 , $+0.790,+0.771$ and +0.910 at $5-10 \mathrm{~cm}$ depth respectively $(P<0.01)$, indicating that they have the same source(s) of contamination in the environment.
Furthermore, there was strong positive correlation $(+0.819)$ between $\mathrm{Cr}$ and $\mathrm{Cd}, \mathrm{Cr}$ and $\mathrm{Pb}(+0.788)$ at $0-5 \mathrm{~cm}$ depth and also between $(+0.750) \mathrm{Cu}$ and $\mathrm{Pb}$ at $5-10 \mathrm{~cm}$ also indicating that they have the same source(s) of contamination in the environment.

Table 4: Correlations matrix of the physicochemical parameters and the metals of soil at 0 - 5 cm depth

\begin{tabular}{|c|c|c|c|c|c|c|c|c|}
\hline & pH & EC & CEC & $\mathbf{C r}$ & $\mathbf{C u}$ & Cd & $\mathbf{P b}$ & $\mathbf{N i}$ \\
\hline $\mathrm{pH}$ & 1.00 & & & & & & & \\
\hline EC & 0.34 & & & & & & & \\
\hline CEC & $0.75 * *$ & $0.74 * *$ & 1.00 & & & & & \\
\hline $\mathrm{Cr}$ & 0.28 & -0.09 & 0.27 & 1.00 & & & & \\
\hline $\mathrm{Cu}$ & -0.09 & 0.19 & -0.01 & 0.60 & 1.00 & & & \\
\hline $\mathrm{Cd}$ & 0.18 & -0.30 & 0.11 & $0.819 * *$ & 0.41 & 1.00 & & \\
\hline $\mathrm{Pb}$ & 0.19 & -0.05 & 0.29 & $0.788 * *$ & 0.54 & $.874 * *$ & 1.00 & \\
\hline $\mathrm{Ni}$ & 0.14 & 0.04 & 0.23 & $0.927 * *$ & $0.80 * *$ & $0.79 * *$ & $0.86 * *$ & 1.00 \\
\hline
\end{tabular}

$* *$. Correlation is significant at the 0.01 level (2-tailed). *. Correlation is significant at the 0.05 level (2-tailed).

Table 5: Correlations matrix of the physicochemical parameters and the metals of soil at $5-10 \mathrm{~cm}$ depth

\begin{tabular}{lllllllll}
\hline & pH & EC & CEC & Cr & Cu & Cd & Pb & Ni \\
\hline $\mathrm{pH}$ & 1.00 & & & & & & & \\
$\mathrm{EC}$ & 0.30 & 1.00 & & & & & & \\
$\mathrm{CEC}$ & $0.71 *$ & $0.74 * *$ & 1.00 & & & & \\
$\mathrm{Cr}$ & 0.27 & 0.36 & 0.60 & 1.00 & & & \\
$\mathrm{Cu}$ & -0.06 & -0.11 & -0.26 & 0.34 & 1.00 & & \\
$\mathrm{Cd}$ & 0.27 & -0.31 & 0.12 & 0.41 & 0.28 & 1.00 & & \\
$\mathrm{~Pb}$ & 0.05 & -0.20 & -0.02 & 0.53 & $0.75 * *$ & $.771^{*} *$ & 1.00 & \\
$\mathrm{Ni}$ & 0.07 & 0.05 & 0.16 & $0.77 * *$ & $0.79 * *$ & 0.60 & $0.91 * *$ & 1.00 \\
\hline$* *$. Correlation is significant at the 0.01 level (2-tailed), *. Correlation is significant at the \\
0.05 level (2-tailed)
\end{tabular}

Table 6: ANOVA metal locations

\begin{tabular}{llrrrrr}
\hline & Source & \multicolumn{1}{c}{$\begin{array}{c}\text { Type III } \\
\text { Sum of } \\
\text { Squares }\end{array}$} & df & \multicolumn{1}{c}{$\begin{array}{c}\text { Mean } \\
\text { Square }\end{array}$} & F & Sig. \\
\hline $\begin{array}{l}\text { Test of within- } \\
\text { subject Effects }\end{array}$ & metals & 7920417.957 & 1.268 & 6244900.683 & 15.980 & 0.000 \\
& metals * location & 10258321.799 & 12.683 & 808823.488 & 2.070 & 0.053 \\
$\begin{array}{l}\text { Test of Between- } \\
\text { Subjects Effects }\end{array}$ & Intercept & 10904130.517 & 27.903 & 390792.119 & & \\
& $\begin{array}{l}\text { location } \\
\text { Error }\end{array}$ & 6423279.073 & 1 & 6423279.073 & 24.166 & 0.000 \\
& 4824071.844 & 10 & 482407.184 & 1.815 & 0.117 \\
\hline
\end{tabular}

*There are significant differences $(\mathrm{P}<0.05)$ within the levels of metal pollution in each site.

\section{CONCLUSION}

The soil heavy metals $(\mathrm{Cr}, \mathrm{Cu}, \mathrm{Cd}, \mathrm{Ni}$ and $\mathrm{Pb}$ ) analyses from the ten selected locations in old Panteka market industrial area was carried out in comparison with the control soil samples and the environmental soil guidelines. The results reveals that all the locations were considerably polluted with heavy metals and most of them have heavy metal concentrations above the intervention/alert level provided by the environmental protection agencies as compared with those of control. The results also shows that heavy metal availability and distribution pattern varies with location and depth as indicated by the wide range of concentration values observed for virtually all the heavy metals in the soils analyzed across the sample locations. The correlation analysis shows that most of the heavy metals are positively correlated with one another thus indicating there common environmental contamination origin. 


\section{REFERENCES}

Abii, T.A. (2012). Levels of heavy metals (Cr, Pb, Cd) available for plants within abandoned mechanic workshops in Umuahia Metropolis. Research journal of chemical sciences, 2(2): 79-82.

Adewole, M. B., Sridhar, M. K. C., \& Adeoye, G. O. (2010). Removal of heavy metals from soil polluted with effluents from a paint industry using Helianthus annuus L. and Tithonia diversifolia (Hemsl.) as influenced by fertilizer applications. Bioremediation Journal, 14(4), 169-179.

Adriano DC(1986) : Trace elements in the terrestrial environment, Springer-Verlag, New York; .

Aloysius, A.P., Sha'Ato, R.and Offem, J.O., (2013).Contributions of Automobile Mechanic Sites to Heavy Metals in Soil: A Case Study of North Bank Mechanic Village Makurdi, Benue State, Central Nigeria. Journal of environmental Chemistry and ecotoxicology, 3(3):2337-2347.

Aruleba JO, Ajayi AS. (2012) Heavy metal pollution status of soils in some locations at Ado Ekiti, Southwestern Nigeria. International Journal of Agricultural Science.2(3):256-264.

Atiemo, M., Ofosu, F. G., Aboh, I. J. K.and Oppon, O. C. (2012). Levels and sources of heavy metal contamination in road dust in selected major highways of Accra, Ghana. Sampson $X$-Ray Spectrometry, 41(2): 105- 110.

Awode, U.A., Uzairu, A., Balarabe, M.L., Harrison,G.F.S. and Okunola, O.J. (2008). Assessment of peppers and soils for some Heavy metals from irrigated farmlands on the banks of river Challawa, Nigeria. Pakistan journal of nutrition, 7(2): 244 248.

Awofolu OR.( 2005) : A survey of trace metals in vegetation, soil and lower animals along some selected major roads on metropolitan city of Lagos. Environ. Monit. Assess. 2005; 105:413-447.

Black C. A. (1965). Methods of Soil Analysis. American Society of Agronomy, Maduson,Wisconsin, U.S.A. Vol. 1,19.

Boularbah A, Schwartz C, Bitton G, Aboudrar W, Ouhammou A, Morel JL(2006):. Heavy metal contamination from mining sites in South Morocco: 2.Assessment of metal accumulation and toxicity in plants. Chemosphere.;63:811-817.

Bouyoucos $\mathrm{GH}(1951)$ : A recalibration of the hydrometer method for making mechanical analysis of Soils. Agronomy Journal. ;43:434-438.

Cook, J. (1976). Environmental Pollution by heavy metals. International Journal of Environmental Studies, 9, 253 - 256.

De Neve, S., Van De Steene, J., Hartman, R. and Hofman, G. (2000).Using time domain reflectometry for monitoring mineralization of nitrogen from soil organic matter. European Journal of Soil Science,51:295304.

Disc, H. M(1981).Environmental Pollution. New York: John Wiley and sons District of Ghana. Environmental Research Journal5(2): 31-37

Elaigwu, S.E., V.O. Ajibola and F.M. Folaranmi, (2007).Studies on the impact of municipal waste dump on surrounding soil and air quality of two cities in Northern Nigeria. J. Applied Sci., 7: 421-425.

Elliott, H.A., Liberati, M.R., and Huang, C.P. (1986).Competitive adsorption of heavy metals by soil. Journal of Environmental Quality, 15: 214-219. environment; assimilated techniques. Environment International 18 (3), 283 -294.

European Commission (EC) (1986). European Commission office for official publications of the European Communities, Luxembourg, Council Directive 66/27/EEC on the protection of the environment and in particular of the soil, when sewage sludge is used in agriculture.

Evans, L.J. (1987). Chemistry of metal retention by soils. Environmental science and Technology, 23: 1046-1056.

FEPA, Federal Environmental Protection Agency (1991).Guidelines and Standard for Environmental Pollution Control in Nigeria. Federal Republic of Nigeria, Nigeria. 61-63.

Gillman, G.P. (1981) Effect of pH and Ionic Strength on the Cation Exchange Capacity of Soils with a Variable Charge. Australian Journal of Soil Research, 19, 93-96. http://dx.doi.org/10.1071/SR9810093

Gupta, A.K. and Sinha, S. (2006). Chemical fractionation and heavy metal accumulation in the plant of Sesamum indicum (L.) Var. T55 grown on soil amended with tannery sludge: selection of single extractants. Chemosphere, 64: 161-173.

Ilemobayo, O. and Kolade I.(2008).Profile of Heavy Metals from Automobile Workshops inAkure, Nigeria. Journal of Environmental Science and Technology, 1, 19-26.

Inobeme A, Ajai AI, Iyaka YA, Ndamitso $M$ and Uwem B (2014). Determination of Physicochemical and heavy metal content of soil around paint industry in Kaduna. Int $\mathrm{J} \mathrm{SCi}$ Tech Res 3: 221-225.

Ipeaiyeda AR, Dawodu M (2008). Heavy metals contamination of topsoil and dispersion in the vicinities of reclaimed auto-repair workshops in Iwo, Nigeria. Bulletin of the chemical society of Ethiopia.22.3: 339-348

Iwegbue, C.M.A., Nwajei, G.E., Eguavon, O. and Ogala, J.E. (2007). Chemical fractionation of some heavy metals in soil profiles in the vicinity of scrap dumps in Warri, Nigeria. Chem Spec Bioavailability.21(2): 99-110. 
Jung, M.C. (2006). Heavy metal contamination of soils and waters in and around the Imcheon Au-Ag mine, Korea. Applied Geochemistry, 16 (11-12), 1369-1375

Kirpichtchikova T, Manceau A, Spadini L, Panfili F, Marcus MA, Jacquet T. Speciation and solubility of heavy metals in contaminated soil using X-ray microfluorescence, EXAFS spectroscopy, chemical extraction, and thermodynamic modeling, Geochimica et Cosmochimica Acta. 2006;70(9):2163-2190.

Lee, M. K., \& Saunders, J. A. (2003). Effects of pH on metals precipitation and sorption. Vadose Zone Journal, 2(2), 177-185.

Luter, L., Akaahan, T.J., Attah, S. (2011). Heavy metals in soils of auto-mechanic shops and refuse dumpsites in Makurdi, Nigeria. Journal of Applied Science and Environmental Management.15(1): 207-210.

Nwachukwu, $H$. Feng, and J. Alinnor, (2010).Assessment of heavy metal pollution in the soil and their implications within and around mechanic villages. Int. J. Environ. Sci. Tech, 7 (2), 347-358.

Nwachukwu, M.A., Feng, H. and Alinnor, J. (2011). Trace metal Deposition in soil from Automechanic village to urban residential areas in Owerri, Nigeria. Proceedings of Environmental Science.4: 310-322.

Odukoya, O. O., Arowolo, T. A., \& Bamgbose, 0. (2000). $\mathrm{Pb}, \mathrm{Zn}$, and $\mathrm{Cu}$ levels in tree barks as an indicator of atmospheric pollution. Environment International, 26(1), 11-16.

Ogunfowokan, A. O., Oyekunle, J. A. O., Dorosinmi, L. M., Akinjokun, A. I. and Gabriel, O.D. (2009). Speciation study of lead and manganese in roadside dust from major roads in Ile-Ife, South Western Nigeria. Journal of Chemistry and Ecology, 25(6): 405-415.

Oguntimehin, I., Ipinmoroti, K.O. (2008). Profile of heavy metals from automobile workshops in Akure, Nigeria. Journal of Environmental Science and Technology1(7):19 - 26.

Okoro , A.C., Chukwuma, G.O., Chukwuma, E. C., Nwachukwu , P.C. and Ezeh, K.A. (2013). Investigating the Effects Of Selected Heavy Metals On Topsoil At The Vicinities Of Two Automobile Mechanic Villages, Owerri Municipal, Nigeria. The International Journal of Engineering and Science, 2(11): 19-26.

Omar A, Al-Khashman. Heavy metal distribution in dust, street dust and soils from the work place in Karak Industrial Estate, Jordan, Atmospheric Environment. 2004; 38:6803 6812.
Osakwe SA (2014). Heavy metal contamination and physicochemical characteristics of soilsfrom automobile workshops in Abraka, Delta State, Nigeria. Int J Nat Sci Res2(4): 48-50.

Osakwe, S. A.and Otuya, O. B. (2008).Elemental Composition of Soils in Some Mechanic Dumpsites in Agbor, Delta State, Nigeria.31st Annual International Conference and Exhibition. Deltachem 2008 Conference Proceedings, $557-559$.

Osaze, O.J, Obayagbona, O.N, and Daniel, E.O. (2013) Microbiology and Physicochemical analyses of top soils obtained from four municipal waste dumpsite in Benin City, Nigeria. International Journal of Microbiology and mycology, 1 (1): 23-30

Oviasogie, P.O., and Omoruyi, E. (2007).Levels of heavy metals and physicochemical properties of soil in a foam manufacturing industry. Journal of Chemical Society of Nigeria, 32(1): 102 - 106.

Rajaković-Ognjanović, V. N., \& Onjia, A. E. (2013). Analytical methods for arsenic speciation analysis. J. Serb. Chem. Soc, 78(10), 14611479.

Smith J, Doran JW (1996) Measurement and use of $\mathrm{pH}$ and electrical conductivity for soil quality analysis. In 'Methods for assessing soil quality'. (Eds JW Doran, AJ Jones) 169185. (American Society of Agronomy Inc.: Madison, WI).

Uba, S., Uzairu, A., Harrison, G.F.S., Balarabe, M.L., and Okunola, O.J. (2008). Assessment of heavy metals bioavailability in dumpsites of Zaria metropolis, Nigeria African Journal of Biotechnology, 7(2): 122-130.

Udousoro, I.I., Umoren, I.U. and Asuquo, E.O. (2010).Survey of some heavy metal concentrations in selected soils in South Eastern parts of Nigeria.World Journal of Applied Science and Technology. 2(2): 139141.

Yahaya, M. I., Mohammad, S. and Abdullah, B. K. (2009). Seasonal variations of heavy metals concentration in abattoir dumping site soil in Nigeria. Journal of Applied Sciences and

Yoon J, Cao X, Zhou Q, Ma LQ. Accumulation of Pb, $\mathrm{Cu}$ and $\mathrm{Zn}$ in native plants growing on a contaminated Florida site. Sci Total Environ. 2007; 368:456-464. 